\title{
Le cuivre, le fer et le souffle humain. Culture et technique dans la fonte andine préhispanique
}

\section{Stephen M. Esptein}

\section{(2) OpenEdition}

\section{Journals}

Édition électronique

URL : https://journals.openedition.org/tc/487

DOI : $10.4000 /$ tc. 487

ISSN : 1952-420X

Éditeur

Éditions de l'EHESS

\section{Édition imprimée}

Date de publication : 1 octobre 1996

ISSN : 0248-6016

\section{Référence électronique}

Stephen M. Esptein, « Le cuivre, le fer et le souffle humain. Culture et technique dans la fonte andine préhispanique », Techniques \& Culture [En ligne], 27 | 1996, mis en ligne le 28 octobre 2005, consulté le 29 septembre 2022. URL : http://journals.openedition.org/tc/487 ; DOI : https://doi.org/10.4000/tc 487

Ce document a été généré automatiquement le 29 septembre 2022.

Tous droits réservés 
Le cuivre, le fer et le souffle humain. Culture et technique dans la fonte andine préhispanique

Stephen M. Esptein 